\title{
Construction logistics governing guidelines in urban development projects
}

Mats Janné and Anna Fredriksson

The self-archived postprint version of this journal article is available at Linköping University Institutional Repository (DiVA):

http://urn.kb.se/resolve?urn=urn:nbn:se:liu:diva-160459

N.B.: When citing this work, cite the original publication.

Janné, M., Fredriksson, A., (2019), Construction logistics governing guidelines in urban development projects, Construction Innovation, 19(1), -109. https://doi.org/10.1108/ci-03-2018-0024

Original publication available at:

https://doi.org/10.1108/ci-03-2018-0024

Copyright: Emerald

http://www.emeraldinsight.com/ 


\title{
Construction Logistics Governing Guidelines in Urban Development Projects
}

\author{
Word count: 7749
}

\begin{abstract}
Purpose: Although a construction logistics solution is necessary for dealing with the demands in many large urban development projects, there is a lack of research on governance mechanisms for construction logistics solutions. Therefore, the purpose is to analyse the initiation and utilisation of a construction logistics centre (CLC) from different stakeholders' perspectives in order to suggest governance mechanisms for strategic, tactical, and operational levels and to develop guidelines for implementing these governance mechanisms.
\end{abstract}

Design/methodology: A single case research design was used. Data were collected through interviews, site visits, observations and documentation from four stakeholder groups.

Findings: There is potential for utilising CLCs in development projects, with positive effects such as consolidation effects and enhanced planning. What is evident, however, is that the design and implementation of the CLCs must be based on a comprehensive stakeholder analysis, as there are conflicting goals between stakeholders. Governance mechanisms including flexibility in the main contractors' working construction process as well as clearly stated roles, responsibilities and communication must be developed to enhance this potential.

Research implications: The conflicting goals of CLCs are identified and discussed, and the results show the need for further multi-stakeholder analysis of construction logistics solutions.

Practical implications: The experiences from the studied case are developed into practical guidelines to be used in the design of construction logistics solutions in development projects.

Originality/value: This study contributes by taking a multi-stakeholder perspective on CLCs and providing guidelines to be used in the design of construction logistics solutions in development projects.

Keywords: construction logistics, construction logistics centres, third-party logistics, governance, stakeholders

Article classification: Research paper 


\section{Introduction}

Although a construction logistics solution is necessary for dealing with the demands in many large urban development projects, such as limited space, reduction of environmental impact, improved accessibility and noise restrictions (cf. Dablanc, 2007), the phenomenon of logistics solutions is relatively new in the construction industry (Langley, 2016). One type of logistics solution is a construction logistics centre (CLC), which is often run by a third-party logistics (TPL) provider (cf. Lindén and Josephson, 2013; Ekeskär and Rudberg, 2016). One benefit of this is that the CLC and TPL provider can act as systems integrators, coordinating materials and resource deliveries to sites within the development area, thereby allowing for less transport and improved efficiency (cf. Ekeskär and Rudberg, 2016). However, since TPL providers traditionally have not been active in the construction industry and logistics solutions are still a novelty, the introduction of CLCs in the construction supply chain will impose new demands regarding governance.

Governance mechanisms are for dealing with how social and economic coordination should take place within a specific area (Williamson, 1999). Yet owing to the paucity of studies on CLCs, there is limited information on how they can be initiated and organised. The few existing studies are all descriptive in nature and from one or two stakeholder perspectives, and lack suggestions on organising construction logistics in urban development projects - namely, developing governance mechanisms guidelines considering different stakeholder perspectives. Ekeskär and Rudberg (2016) and Sundquist, et al. (2017) both studied CLCs and their governance impact in specific projects. Some reports and theses have also investigated the use of CLCs in, for example, London and Stockholm (cf. Lundesjo, 2010, 2011; Brunge, 2013). What these studies reveal is that the initiation of CLCs has not been without resistance from 
stakeholders in the construction supply chain. Therefore, the present study's purpose was to analyse the initiation and utilisation of a CLC from different stakeholders' perspectives and in order to suggest governance mechanisms for strategic, tactical, and operational levels and to develop guidelines for implementing these governance mechanisms. The research was based on a single case study of a CLC in a major urban development project in Sweden. Data were collected through semi-structured interviews with the TPL provider, the municipality, three different main contractors and two developers, and through project documentation. To achieve the purpose of the study, two research questions were formulated:

RQ1: What are the experiences of different stakeholders (municipality, developers, TPL provider and main contractors) of using a CLC in a large urban development project? RQ2: Based on the experiences of the different stakeholders, what are important aspects to consider when developing construction logistics governance mechanisms in urban development projects?

\section{Theoretical framework}

\section{Construction logistics and construction logistics centres}

Construction logistics can be defined as all activities dealing with supplying the right materials and resources to the correct customer and construction site to meet the customer's requirements. Some examples are planning (Thunberg and Persson, 2014), supplying and maintaining loading and unloading zones (Transport for London, 2013), on- or off-site warehousing (Lundesjo, 2010, 2011) and on- and off-site materials handling (Lindén and Josephson, 2013; Ekeskär and Rudberg, 2016).

Construction occurs on a project basis in temporary organisations, creating new, temporary supply chains, and each construction site requires a new logistics setup, as the location is unique (Dubois and Gadde, 2002). Construction projects produce the end 
product (houses or infrastructure) at the place of consumption (cf. Ekeskär and Rudberg, 2016); therefore, numerous materials and resources must be delivered to, and removed from, each site at the correct time (cf. Lindén and Josephson, 2013). This creates additional transport flows and a competition for existing urban infrastructure with other traffic users. These additional transports affect the urban environment negatively (cf. Dablanc, 2007; Bretzke, 2013). One popular suggestion for reducing the impact of transporting urban goods is consolidating goods from multiple suppliers into one shipment to reduce the amount of goods moving in cities (Allen, et al., 2014; Björklund, et al., 2017). This idea is now receiving attention in the construction industry, paving the way for CLCs, which are either located in close proximity to the construction area or as a warehouse solution farther away with a check-point at the construction site (Lundesjo, 2011; Transport for London, 2013).

A CLC can be initiated by different stakeholders, such as the developer (Ekeskär and Rudberg, 2016) or municipality (Transport for London, 2013). The aim of the CLC is to coordinate deliveries to multiple construction sites within an urban area (Lundesjo, 2010, 2011; Brunge, 2013; Transport for London, 2013). Consequently, some of the performance measures used to assess the impact of the CLC are the number of transports, delivery precision, fill rates, consolidation effect, emissions, noise, safety, and costs (Transport for London, 2013; Bergman, 2016). These performance measures are however very transport oriented. When measuring performance in general also quality, delivery times and flexibility are seen as important performance measures to consider the production operations as well (Slack, et al., 2001).

CLCs are often run by TPL providers (Lindén and Josephson, 2013; Ekeskär and Rudberg, 2016). The essence of the TPL concept can be captured as involving businessto-business relationships where third parties fulfil the needs of their clients in the supply 
chain in which they are operating (Marasco, 2008). The TPL provider offers through the CLC multiple logistics services over a contractually fixed period (Selviaridis and Spring, 2007). TPL can include services such as transport, warehousing, inventory management (e.g. materials handling, repackaging), value-adding activities (e.g. secondary assembly, installation of products), information-related activities (e.g. tracking and tracing, distribution planning), as well as the design and reengineering of the supply chain (van Laarhoven, et al., 2000; Hertz and Alfredsson, 2003). The scope of the services provided depends on whether the TPL provider has their own (physical) assets or not. Asset-based providers own physical assets, such as truck fleets and warehouses, and focus on the management and execution of transport- and warehouserelated activities (Selviaridis and Spring, 2007). Non-asset-based providers rely on human expertise and information systems and offer management-oriented services, subcontracting physical distribution activities to asset-based companies (Selviaridis and Spring, 2007).

TPL providers have been used in other industries since the early 1990s (cf. Berglund, et al., 1999). The main differences between the consolidation efforts of the construction and other industries lie primarily in the types of materials handled and volumes managed. In construction, the materials vary in size and volume between project phases (Akintoye, 1995). The use of CLCs has been mainly to handle large volumes of materials, such as plasterboard and rafters (cf. Lundesjo, 2010; Lindén and Josephson, 2013). The most common procedure is for materials to arrive from different suppliers to the CLC, where they are received, controlled, registered and stored (Lundesjo, 2010, 2011). When a construction site calls off materials, they are picked and sent to the site. Some value-adding services can also be delivered beforehand, such as kitting, where materials for a room or apartment are combined into a full bill-of- 
materials for an installation spot (Lundesjo, 2010). This can alleviate some issues onsite; having only the materials needed for installation reduces congested sectors and the risks that this entails (Lindén and Josephson, 2013; Ekeskär and Rudberg, 2016). Another value-adding activity of CLCs is the coordination of bookings through joint IT platforms (Lundesjo, 2010, 2011; Brunge, 2013). This forces contractors to plan their material flows according to when they need the materials and allows the TPL provider to manage and control material flows on-site. Using the CLC as a coordinating contact point allows the main contractors to focus on their operations rather than on establishing contacts and coordinating deliveries with multiple other contractors within the same construction area (cf. Lindén and Josephson, 2013; Sundquist, et al., 2017).

\section{Governance}

Managing projects in complex environments is difficult due to high levels of uncertainty and the involvement of many different stakeholders (Locatelli, et al., 2014). Thus, it is important to consider different stakeholders' concerns at an early stage of the process (Dablanc, 2007; Ballantyne, et al., 2013; Jereb, 2017). For a CLC to be efficient, regulations must be agreed upon by all stakeholders (Lundesjo, 2011; Boissinot and Paché, 2011; Transport for London, 2013). However, establishing these regulations depends on the ruling governance mechanisms. Hufty (2011:405) defines governance as 'the processes of interaction and decision-making among the actors involved in a collective problem that lead to creation, reinforcement or reproduction of social norms and institutions'. Boissinot and Paché (2011) highlight that governance can be used as a means to monitor, select, incentivise or socialise relationships amongst stakeholders with the purpose of aligning interests and reducing information asymmetry. Governance mechanisms can, thus, be seen as a strategy for undertaking social and economic coordination within a specific area (Williamson, 1999; Jereb, 
2017). This can be translated into three levels of governance: strategic, tactical and operational (Boissinot and Paché, 2011). The strategic level concerns setting long-term goals and guidelines, the tactical level deals with how to achieve the long-term goals through regulations and incentives, and operational governance entails setting the rules for daily activities (Schmidt and Wilhelm, 2000; Boissinot and Paché, 2011).

Regardless of how the governance mechanisms are designed, some control mechanisms must be in place to ensure that stakeholders adhere to the set regulations and do not act opportunistically (Caldwell, et al., 2009). Formal control is often applied as contractually stipulated regulations (Caldwell, et al., 2009), leading to an adversarial relationship between the parties in the relationship (Winch, 2001; Boissinot and Paché, 2011). It is important to note that different stakeholders have different drivers and needs from the governance mechanisms; private actors are driven by financial considerations, whereas public authorities are driven by providing public value (Teisman and Klijn, 2004; Caldwell, et al., 2009). As friction and challenges between the public and private sectors will occur, the right governance enablers are important for facilitating decision making and operations when setting up a logistics solution (cf. Norrman and Henkow, 2014; Jereb, 2017).

\section{Conceptual summary}

The experience of the CLC depends on both the specific logistics solution and the governance mechanisms (Caldwell, et al., 2009), as there is an interplay between these two. Finding optimal governance mechanisms is difficult in urban development projects, as there is a trade-off between control and commitment (van Marrewijk, et al., 2008) and each project in some way requires unique organisation (Flyvbjerg, 2007).

The strategic level of construction logistics governance entails the initiating stakeholder (e.g. municipality, developer or main contractor) identifying the aim of the solution - 
that is, what performance the solution should provide (e.g. decrease in transports, improvement in productivity). At the tactical level of governance, depending on the aim of the construction logistics solution from the strategic level, what services to provide, where to locate them and how to organise them must be defined by the stakeholders initiating, operating and utilising the solution (e.g. TPL provider and contractors). At the operational level, these services are carried out by the TPL provider depending on the demands of the different stakeholders utilising them (e.g. contractors and developers). Figure 1 highlights the importance of evaluating the logistics solution and governance mechanisms at the strategic, tactical and operational levels (Schmidt and Wilhelm, 2000; Boissinot and Paché, 2011) to capture the relationship between the strategic design decisions early in the project and the actual operations of the construction logistics solution during production later in the project.

\footnotetext{
**Insert Figure 1 here**
}

\section{Methodology}

A single case research design was selected because it allows for an in-depth understanding of mechanisms (cf. Eisenhardt, 1989; Flyvbjerg, 2006). The studied case and the unit of analysis was the CLC within the Stockholm Royal Seaport (SRS). Four perspectives of the CLC were studied: the City of Stockholm, the operating TPL provider, three main contractors and two developers. The relationships between the actors are presented in Figure 2. The City of Stockholm has a development office in the SRS area which is responsible for the development project. The TPL provider is an experienced TPL provider from the mechanical industry. However, SRS was one of their first construction projects. The three main contractors are building between one 
and three apartment buildings within the SRS with time frames for the projects ranging between 23 and 33 months. Developer 1 (D1) is a municipal housing company and frequently sources contractors on turn-key contracts. Developer 2 (D2) is a private housing company undertaking all projects with in-house personnel.

\section{**Insert Figure 2 here**}

The case study was conducted through an iterative process based on Yin (2014) (see Figure 3). The case was prepared through a comprehensive literature review comprising construction logistics, construction logistics centres and governance. The main focus of the literature review was on building a theoretical foundation for the case study, thus taking in broad aspects of the three areas. This approach also strengthened the reliability of the study, as the findings from the empirical work can be compared to the literature (Voss, 2009; Yin, 2014). The literature review was conceptualised into an analytical framework (see Figure 1). For the data collection, interview guides and case study protocols were developed during the preparation phase (Appendix 1). These were revisited continuously during the study to improve the data collection process.

\section{$* *$ Insert Figure 3 here $* *$}

Data were collected in 2016 and 2017 via 11 semi-structured interviews, on-site observations and documents. The interviews were aimed at capturing both the positive and negative experiences of the stakeholders regarding the operations of the CLC as well as the governance mechanisms connected to it. The CLC was visited four times and the construction sites were visited once each to provide a detailed, in-depth 
description of the operations. Documents such as CLC evaluation reports, price lists, project documents and site layout plans were collected to enhance the description of the

CLC. The iterative nature of the case study alongside the use of multiple data collection methods and sources helped to strengthen the validity and reliability of the paper through data triangulation (Voss, 2009; Yin, 2014). Key informants also reviewed draft case study reports (Voss, 2009; Yin, 2014).

The stakeholders' experiences were used to answer RQ1. To answer RQ2, the stakeholder experiences were compared in a structured way with the help of the analytical framework (Figure 1).

\section{Case description: Stockholm Royal Seaport CLC}

In the Stockholm Royal Seaport (SRS), 12,000 new homes and 35,000 new workplaces are to be built. The development area spans 236 hectares with a total investment in SRS approximated at $€ 2.2$ billion. The planning of the development project started in the early 2000s and ground was broken in 2011 with planned completion in 2030.

\section{SRS CLC}

The CLC solution comprises four parts: the terminal and its operations, traffic piloting, education, and perimeter fencing and security. The CLC is largely funded by the developers' connection fee and through different service charges. All services are stipulated in a price list available on the CLC's website. Each construction site has its own unloading zone. Table 1 explains the SRS CLC and Figure 4 schematically shows the procedure of the CLC.

**Insert Table 1 here** 


\section{**Insert Figure 4 here $* *$}

\section{SRS Governance Mechanisms}

In 2009, the Stockholm city council decided that the SRS would become one of four new sustainable areas in the city, and the development of a logistics solution for the area was initiated. Based on a logistics analysis in 2011, a CLC close to the development area was opened in 2013. The aim was to reduce the amount of construction traffic in the area and allow for sustainable transport solutions. The CLC has mandatory accession for contractors and developers acting within the SRS and is governed through contractual agreements between the City of Stockholm, TPL providers, developers and contractors. It is stipulated in the land allocation agreements that developers are required to inform their contractors of the CLC and the mandatory use of basic services offered in the solution. The following rules were set by the city for how the CLC should function:

(1) Mandatory accession to the CLC regulated in the land allocation agreement

(2) All incoming transports must be booked into a transport booking system

(3) No material storage on-site

(4) Common waste disposal with smaller waste containers on-site

(5) Common perimeter fencing with gates

(6) Consolidation of all material deliveries under a certain volume

(7) Vehicles larger than 12 metres must have a special permit to enter construction sites 


\section{City of Stockholm experience}

The CLC has decreased the environmental impact of construction logistics. There have been estimated consolidation effects of $40-60 \%$ compared to traditional construction projects (Bergman, 2016). However, these effects could have been larger if unnecessary direct transports, tail-gating and other avoidance strategies from users had been minimised. The main issue with the CLC setup has been to 'sell' it to all parties. The City of Stockholm includes demands regarding the mandatory accession of the CLC in the land allocation agreements with developers. The developers should then communicate this to the contractors, who in turn should inform their subcontractors. The City of Stockholm has experienced the developers being passive in their communication of demands to the contractors. The developers have experienced some animosity from contractors, who feel that they have not been properly introduced to the CLC and its working practices.

According to the municipality, the financing of the CLC must be through the services that it provides. Further, developers and contractors have been reluctant to use the CLC to a greater extent than the mandatory basic services.

\section{TPL service provider's experience}

By consolidating smaller transports, and with the help of the planning tool and issuing gate codes, the movement of goods has been controlled within the development area. Nonetheless, there have been problems, where contractors booked entire days for direct deliveries, rather than the time needed for delivering and unloading goods on-site. According to the TPL provider, this is partly due to the difficulty of selling the overall solution to contractors. The TPL provider wishes to provide contractors with a good overall experience while building in the SRS. However, contractors have been reluctant to use the solution. For example, few contractors have bought other services besides the 
mandatory basic services. Over time, the CLC setup has changed to better comply with the needs of contactors working in the SRS. One such example is going from an activity-based pricing model to hourly rates. This was in reply to criticism from main contractors who experienced, for example, that unloading at their site was less timeconsuming than at other sites. The TPL provider saw potential for developing the CLC further to better meet the contractors' demands. For example, the TPL provider was considering having trucks and machinery on-site to allow contractors to rent the machinery for the required time, rather than for full days. Simultaneously, the TPL provider was trying to tighten up the time window requirements on entry and unloading in the development area to improve the control of traffic flows within the SRS. The TPL provider was aware that contractors wish the CLC could also handle large and heavy materials.

\section{Experience of the three main contractors}

Main contractor 1 (MC1) had been operating in the SRS since before the launch of the CLC solution. With their experience, they deemed it necessary to have a logistics manager on site to coordinate with the CLC. Main contractor 2 (MC2) used the CLC as much as possible, as it was stipulated by their client. MC2 also used a logistics manager on site. Main contractor 3 (MC3), however, divided the role of logistics manager between different site managers and foremen. MC3 used the CLC to a minimum, partly due to their in-house logistics concept and partly because management did not prioritise using the CLC. Overall, it was not until the construction entered the interior phases that MC3 saw the potential of the CLC. Both MC2 and MC3 would have liked to be able to store larger elements and materials at the CLC, which was not possible due to size restrictions. 
There was some flexibility in the relationship between MC2 and the TPL provider, especially when regarding gates and boundary fencing. Initially, there were some issues with gate codes not working; thus, MC2 asked to have the same code one week at a time, which the TPL provider allowed. Owing to this good relationship, most of MC2's larger subcontractors directed all their materials through the CLC. MC1 also acknowledged that the TPL provider had tried to be as flexible as possible towards contractors. For instance, the stipulated one-week planning window was reduced to twoto-three days for MC1 in some cases. MC1, however, highlighted that in the early days of the CLC, there were many problems. They attributed this to the TPL provider being new to the construction context.

From MC3's perspective, governance and logistics in the SRS were troublesome. Located at the end of an enclosed block, MC3's construction site was last in line for deliveries but situated next to residents in completed phases. Due to their location, MC3's concrete and other delivery trucks had to pass several other unloading zones, which periodically blocked the road. To deal with this, MC3 suggested that a new gate be established closer to the construction site, but the city did not permit this. Furthermore, MC3 needed more unloading zones, which took a long time to negotiate. This delay impacted the construction work, especially during the framing process. Overall, MC3 felt that the municipality lacked an understanding of construction in general and flexibility for dealing with troublesome situations. MC3 mentioned that there was also an information sharing problem from developers to main contractors. In their case, the site management did not know all the conditions and rules of the CLC before the work commenced. Yet MC3 also thought that the information could not be shared too early in the process, as the implications were too abstract to grasp before the 
physical site conditions were known. Furthermore, MC3 highlighted that allowing all contractors to access their construction sites at the same time had proven problematic.

All three MCs were convinced that it would have been impossible to work in the SRS without a logistics solution of some sort. MC3 believed that the thought behind the CLC and the governance of material flows within the SRS was good, and from a microperspective it worked. The number of smaller vehicles was radically reduced in comparison to other projects, making it easier, traffic-wise, to receive larger deliveries on-site. MC3 also saw that consolidation from the CLC to the site worked well, as did the TPL provider's waste management. MC2 saw the consolidation effect and the possibility of storing and calling off materials in smaller batches as positive, as well as the activity coordination meetings held by the TPL provider. According to MC1, this also helped smoothen the process of delivering materials.

MC3's overall impression was that the CLC and governance model were not beneficial for main contractors. MC2 was critical of how the solution was sold to them - as cost saving. In reality, deliveries from wholesalers became more expensive because the CLC charged the contractors for unloading, handling, loading and transporting from the CLC to the site. MC2 would have preferred a solution where the gate passages were free but limited to a fixed number of passages per week. They also saw a need for the pricing of services to come down to a more reasonable level, as the contractors were paying double the usual amount per transport.

All MCs mentioned that considerable time had been allocated to planning and booking. Furthermore, the lead time of deliveries increased by a full day by passing the CLC. According to MC1, it was difficult to convince all craftsmen as well as subcontractors to start communicating material demands to foremen earlier than in traditional projects. At the same time, $\mathrm{MC} 1$ admitted to becoming better at planning and 
that the perceived issue with the longer planning fences might have been due to a lack of experience. According to MC3, the fixed delivery windows of the CLC were almost impossible to work with; two-hour delivery windows were insufficient, as deliveries must pass through Stockholm to get to the SRS area.

\section{Experience of the two developers}

The two developers (D1 and D2) were both experienced and had been operating in the SRS area since before the introduction of the CLC solution. However, as the CLC had been introduced as a mandatory solution, both developers experienced difficulty in setting a budget for the utilisation of the service. D1 decided to bear directly all costs for the utilisation of the CLC and the basic services and added an additional $€ 100,000$ for contractors to utilise the value-adding services of the CLC. However, D2 struggled with the budgeting, but decided to allocate an undisclosed sum for the logistics activities and evaluate the finances on an ongoing basis.

Both developers viewed the information exchange as troublesome. One issue early on was that the municipality and the TPL provider had insufficient knowledge of construction; some regulations had been theoretically developed, and from the developers' point-of-view, they were unfeasible. Both developers had frequent contact with the city and the TPL provider, and the parties learned how to work with each other and develop the regulations. For the latest projects, both developers demanded that the contractors allocate personnel resources to manage logistics at their respective sites. Both developers highlighted that without logistics managers on-site, the projects would have been more difficult to manage.

Neither believed that it would have been possible to build in the SRS area without a logistics solution. Both also recognised that as more housing projects will be undertaken in cities, the industry must accept that construction logistics solutions will 
be their everyday reality. D1 and D2 highlighted the need to establish the concept with those using it - namely, the contractors - and to do so early on in the process to ensure that all stakeholders know how the solution works, why it has been implemented and how it is governed. D2 believed that the responsibility to share information about the solution could reside with the developers. Who should initiate the solution, however, was less clear. D2 pointed out that it would ultimately depend on land ownership, but also what the goal of the solution is. D1 saw that the city has a big responsibility in setting up construction logistics solutions; it is difficult to coordinate 30 developers and contractors without a 'higher power' governing them. Importantly, the solution must work for all construction phases and have demonstrable benefits.

\section{Analysis}

The analysis is organised according to the analytical framework in Figure 1.

\section{Stakeholders' experience of using the CLC}

To answer RQ1, Table 2 summarises the stakeholders' positive and negative experiences. Noticeable is that all stakeholders saw a consolidation or coordination effect and they perceived the major issues as information and knowledge exchange between stakeholders.

\footnotetext{
**Insert Table 2 here**
}

\section{Aspects to consider when developing construction logistics governance mechanisms in urban development projects}

\section{Construction logistics solution}

A terminal solution, such as the one studied, implies increased handling and prolonged 
delivery times for the MCs while opening up possibilities for warehousing close to the site. There were difficulties in diffusing the positive aspects and the potential of the CLC and its utilisation to the MCs. It was not until the later stages of the construction process that the MCs saw the potential of the CLC. This indicates that the CLC and the regulations set for gate passages, unloading zones, etc. cannot be the same throughout the construction project and should be adapted to the different materials during different project phases. This issue was raised by the MCs - specifically, that the CLC could not handle large materials during the early phases, such as concrete elements.

In the studied case, the CLC's physical location was important. The city's demand for the terminal to be close to the construction site was counterintuitive from a logistics point of view, given the goal of having a decreased environmental impact. With this location, transports had to pass through the city before they could be consolidated, which complicated time bookings according to MC3. However, the location of the terminal improved the coordination between the TPL provider and the MCs and allowed for renting out machinery. The selection of a TPL provider with limited construction industry experience created unnecessary resistance and a lack of collaboration among MCs, who argued that the inexperience of the operator meant that the CLC did not work as expected. However, when the operator was selected, there were very few TPL providers with knowledge of both logistics and construction in Sweden. Thus, it was a choice of either logistics or construction knowledge, and since a CLC is mainly a logistics solution, the selection of an experienced TPL provider can be seen as justified.

Furthermore, how the MCs organised themselves in the SRS project was analysed. MC1 and MC2 had dedicated logistics managers and both developers perceived that a dedicated, on-site logistics manager could help the MCs better 
coordinate with, and utilise, the CLC. MC1 and MC2 were prone to utilising the CLC for short-term storage and saw it as a means to achieve better control of deliveries. That on-site logistics managers improved the experience of the CLC may have been due to the site organisations having knowledge and understanding of logistics, but also due to the logistics managers having the time and resources to deal with logistics-related issues (cf. Lundesjo, 2010; Transport for London, 2013). One suggestion is that the city, and subsequently the developers, should start specifying in land allocation agreements and tendering documents that the site organisation must include a logistics manager. This would allow MCs to bring in logistics competence early on in construction projects, allowing for more stable logistics processes.

\section{Governance mechanisms}

The City of Stockholm initiated the solution as a result of their aim to reduce the impact on third parties and increase the environmental sustainability of urban development projects. Thus, the solution was initiated from a top level in relation to bargaining power; that is, the city could impose its solution on the developers and force them to impose the solution on the main contractors. The aim of the solution for the municipality had been clear from the beginning. However, the MCs and developers were told that the use of the CLC would save costs - the goal of using a construction logistics solution. Thus, the municipality tried to get the users of the solution to accept it by presenting a goal that would be of interest to them. However, because of the solution's design, the MCs' goal was not fulfilled, creating disappointment. The MCs and developers all understood the need for a solution within large urban development projects. Had the City of Stockholm provided an explanation relating to the original goals of the CLC, the acceptance of the solution could have improved. To summarise, if the initiation and enforcement are top-down, the openness of the initiator regarding 
goals, benefits to third parties and the overall perspective of the solution may increase the users' acceptance.

At the strategic level, the solution was designed by the City of Stockholm, focusing on governing through contractual agreements with detailed regulations. In the SRS case, many stakeholders are involved, and the contractual relationships are complicated. Contractually, the city acts as both customer and employer of the TPL provider. The developers are suppliers to the city and customers of the TPL provider and MCs. Finally, the MCs are customers of the TPL provider and suppliers to both the city and developers. The city sets the regulations for the TPL provider, developers and MCs. This setup renders the TPL provider stuck in the middle with low authority over the MCs, for whom they should enforce the use of the solution at the operational level, while having limited possibilities to affect the setup of the CLC at the strategic/tactical level. Another problem is that it was unclear who the customer was. This should be clarified already at the strategic level when designing the CLC. This will facilitate information sharing between stakeholders on a tactical level and prioritisation between stakeholder demands by the TPL provider at the operational level. As it was, the developers were expected to transfer knowledge from the city to the MCs. However, both the city and MCs expressed concerns regarding poor information sharing from developers. This implies that the developers do not fully understand their role. As the municipality mentioned, this had also prevented the city from explaining the purpose of the CLC to the MCs and had made it difficult for the TPL provider to explain their operations directly to the MCs.

Another way of organising the governance by granting more autonomy to the TPL provider could allow for improvements of the CLC operations, based on the relationship between the MCs and the TPL provider. This can be seen in the relations 
between MC1 and MC2 and the TPL provider, where flexibility was shown if possible, making the experience more positive from the MCs' side.

The detailed regulations in the SRS had been set early by the city (i.e. at the strategic level). This was done to have set regulations in place before the signing of the land agreement between the city and the developers, thereby making the demands known from the beginning. However, the detailed regulations were obstructive to the work of the TPL provider and the MCs at the operational level. MC3, for example, considered the city to have poor knowledge of construction processes, as shown, for example, in the city's unwillingness to adapt regulations according to the location of the construction site within the area and the construction methods. Both the TPL provider and the municipality expressed concerns that MCs were reluctant to fully utilise the CLC. In their view, the CLC was there to facilitate an efficient construction process, whereas the MCs initially seemed to regard the CLC mainly as an additional and unnecessary step in the delivery process. Thus, if detailed regulations are set early on at the strategic level, there must be flexibility within the operational level for adaptations when the actual work commences, and all requirements are known. Otherwise, acceptance will be low. Furthermore, communication regarding the design of the CLC had been one-way, where the MCs had not been able to provide input regarding the services needed. This led to low mutual understanding among the stakeholders. Alternatively, general rules can be set at the strategic level early on in a project, and thereafter more detailed regulations can be developed at the tactical level once the affected stakeholders are identified. This would allow for stakeholder involvement and alignment between the strategic and operational design levels.

\section{Discussion and conclusions}

The purpose of this study was to analyse the initiation and utilisation of a CLC from 
different stakeholders' perspectives in order to suggest governance mechanisms for strategic, tactical, and operational levels and to develop guidelines for implementing these governance mechanisms.

There must be an alignment between actions taken at the strategic, tactical and operational levels as well as between the design of the construction logistics solution and its governance mechanisms. Table 3 shows guidelines to consider in the design of the CLC. It further shows how these guidelines impact the performance of the solution. The analysis showed that the municipality, the main contractors and the TPL provider all found the consolidation effect of using a CLC to be positive. From the city's and the TPL provider's perspective, this had manifested as a reduction in heavy goods vehicles in and around the development area, reducing traffic and disturbances to third parties. For the MCs, it was a matter of reducing the number of deliveries to the site, thus also reducing the number of times that goods had to be handled by craftsmen and other resources. The developers addressed this as a coordination effect. Though, the acceptance and success of the solution will depend on some actions being taken regarding both the construction logistics solution and its governance as well as what type of performance it is expected to deliver. From the case we can see that the performance focus of the CLC from the designers' point of view (the city) was transport and environmental related effects. However, in Table 4 it can be seen that the wishedfor outcomes by the other stakeholders focus on flexibility, delivery and quality. Thus, a CLC cannot be designed only as a transport solution, it has to be seen as a part of the material flow to the construction sites and thereby more operations related performance measures have to be considered.

\footnotetext{
**Insert Table 3 here $* *$
} 
The findings from this single case study constitute a valuable starting point for further studies. Other projects using CLC and governance solutions should be investigated to explore whether similar findings arise, but it would be possible to also study other logistics and governance solutions. The perspectives of transporters and suppliers must also be studied.

\section{Acknowledgements}

Will be disclosed after review.

Funding details. Will be disclosed after review.

Disclosure statement. No financial interest or benefit has arisen from the direct applications of this research.

\section{References}

Akintoye, A. 1995. Just-in-Time application and implementation for building material management. Construction Management and Economics, 13, 105-113.

Allen, J., Browne, M., Woodburn, A. \& Leonardi, J. 2014. A review of urban consolidation centres in the supply chain based on a case study approach. Supply Chain Forum, 15, 100-112.

Ballantyne, E. E. F., Lindholm, M. \& Whiteing, A. 2013. A comparative study of urban freight transport planning: addressing stakeholder needs. Journal of Transport Geography, 32, 93-101.

Berglund, M., van Laarhoven, P., Sharman, G. \& Wandel, S. 1999. Third-Party Logistics: Is There a Future? The International Journal of Logistics Management, 10, 59-70.

Bergman, F. 2016. Bygglogistikcenter i Norra Djurgårdsstaden - delavstämning. Stockholm: Exploateringskontoret, Stockholms stad.

Björklund, M., Abrahamsson, M. \& Johansson, H. 2017. Critical factors for viable business models for urban consolidation centres. Research in Transportation Economics, $64,36-47$.

Boissinot, A. \& Paché, G. 2011. Opportunism control in exchange relationships: Lessons from the French logistics industry. Problems and Perspectives in Management, 9, 71-77.

Bretzke, W. R. 2013. Global urbanization: A major challenge for logistics. Logistics Research, 6, 57-62. 
Brunge, K. 2013. Förbättrad logistik för byggmaterial i Norra Djurgårdsstaden. Master of Science Master of Science, Royal Institute of Technology.

Caldwell, N. D., Roehrich, J. K. \& Davies, A. C. 2009. Procuring complex performance in construction: London Heathrow Terminal 5 and a Private Finance Initiative hospital. Journal of Purchasing and Supply Management, 15, 178-186.

Dablanc, L. 2007. Goods transport in large European cities: Difficult to organize, difficult to modernize. Transportation Research Part A: Policy and Practice, 41, 280-285.

Dubois, A. \& Gadde, L.-E. 2002. The construction industry as a loosely coupled system: implications for productivity and innovation. Construction Management and Economics, 20, 621-631.

Eisenhardt, K. M. 1989. Building Theories from Case Study Research. The Academy of Management Review, 14, 532-550.

Ekeskär, A. \& Rudberg, M. 2016. Third-party logistics in construction: the case of a large hospital project. Construction Management and Economics, 34, 174-191.

Flyvbjerg, B. 2006. Five Misunderstandings About Case-Study Research. Qualitative Inquiry, 12, 219-245.

Flyvbjerg, B. 2007. Megaproject Policy and Planning: Problems, Causes, Cures. PhD, Aalborg University.

Hertz, S. \& Alfredsson, M. 2003. Strategic development of third party logistics providers. Industrial Marketing Management, 32, 139-149.

Hufty, M. 2011. Investigating Policy Processes: The Governance Analytical Framework (GAF). In: Wiesmann, U. \& Hurni, H. (eds.) Research for Sustainable Development: Foundations, Experiences, and Perspectices. Bern, Switzerland: University of Bern.

Jereb, B. 2017. Mastering logistics investment management. Transformations in Business and Economics, 16, 100-120.

Langley, C. J. 2016. 2016 Third-Party Logistics Study: The State of Logistics Outsourcing.

Lindén, S. \& Josephson, P. E. 2013. In-housing or out-sourcing on-site materials handling in housing? Journal of Engineering, Design and Technology, 11, 90-106.

Locatelli, G., Mancini, M. \& Romano, E. 2014. Systems Engineering to improve the governance in complex project environments. International Journal of Project Management, 32, 1395-1410.

Lundesjo, G. 2010. Barts Hospital, London. Banbury, Oxon, Great Britain.

Lundesjo, G. 2011. Using Construction Consolidation Centres to reduce construction waste and carbon emissions. Banbury, Oxon, Great Britain: Waste \& Resources Action Programme.

Marasco, A. 2008. Third-party logistics: A literature review. International Journal of Production Economics, 113, 127-147.

Norrman, A. \& Henkow, O. 2014. Logistics principles vs. legal principles: frictions and challenges. International Journal of Physical Distribution \& Logistics Management, 44, 744-767. 
Schmidt, G. \& Wilhelm, W. E. 2000. Strategic, tactical and operational decisions in multinational logistics networks: A review and discussion of modelling issues. International Journal of Production Research, 38, 1501-1523.

Selviaridis, K. \& Spring, M. 2007. Third party logistics: a literature review and research agenda. The International Journal of Logistics Management, 18, 125-150.

Slack, N., Chambers, S. \& Johnston, R. 2001. Operations Management, Harlow, Pearson Education Limited

Sundquist, V., Gadde, L.-E. \& Hulthén, K. 2017. Reorganizing construction logistics for improved performance. Construction Management and Economics, 1-17.

Teisman, G. \& Klijn, E. H. 2004. PPPs: torn between two lovers. EBF Debate, 18, $27-$ 29.

Thunberg, M. \& Persson, F. 2014. Using the SCOR models performance measurements to improve construction logistics. Production Planning and Control, 25, 1065-1078.

Transport for London 2013. Construction Logistics Plan Guidance for Developers. Windsor House, London: Transport for London.

van Laarhoven, P., Berglund, M. \& Peters, M. 2000. Third-party logistics in Europe five years later. International Journal of Physical Distribution \& Logistics Management, $30,425-442$.

van Marrewijk, A., Clegg, S. R., Pitsis, T. S. \& Veenswijk, M. 2008. Managing publicprivate megaprojects: Paradoxes, complexity, and project design. International Journal of Project Management, 26, 591-600.

Voss, C. 2009. Case Research in Operations Management. In: Karlsson, C. (ed.) Researching Operations Management. New York: Routledge.

Williamson, O. E. 1999. Strategy research: governance and competence perspectives. Strategic Management Journal, 20, 1087-1108.

Winch, G. M. 2001. Governing the project process: a conceptual framework. Construction Management and Economics, 19, 799-808.

Yin, R. K. 2014. Case Study Research: Design and Methods, Thousand Oaks, California, SAGE Publications, Inc. 


\section{Appendix 1 - Case study protocol}

\section{Context of the specific project}

Time frame

Client (public/private)

Project size

Type of construction project (what is constructed?)

Location of the construction project

Is there something unique about the construction logistics due to:

- The location of the construction site?

- The method of construction?

- Economic cycle?

- Uncertainty or volatility of demand or supply?

\section{Key actors}

What roles and responsibilities do different stakeholders have in the specific project?

What are stakeholders' requirements?

Who decides and about what?

- Regulations

- Stakeholder criteria

- Resource use

- Coordination of activities

How do stakeholders interact?

- Principles for information sharing

- How is knowledge exchanged between actors?

What impact does national laws, regulations and traditions have on stakeholders?

\section{Key resources}

What common key resources (trucks, fork lifts, elevators, load carriers, cranes, ITsystems etc) need to be governed?

How is resource utilization planned and organized? 
Are there some constraints regarding use of resources? (e.g. limited space for storage)

\section{Key activities}

What key activities need to be governed?

How is the construction project planned?

How are activities coordinated?

What impact does the surrounding societal conditions have on activities on site? (i.e. surrounding traffic, regulations regarding noise, traffic zones etc.)

\section{Material flows}

Do you think that material flows in construction projects are problematic?

How much material enters the construction site and what types?

Are the different types managed differently?

From how many suppliers is materials ordered/delivered?

Where are the suppliers located? (distance)

Are materials consolidated before entering the construction site? If yes describe.

Do you use time windows for the transport? If yes, why? Which are the benefits?

How much time is there between ordering of material and expected delivery? Does this differ depending on type of material?

How large share of the project turnover is materials from suppliers?

\section{Governance mechanisms}

What type of contract is used and how is the contract set up?

How is tendering conducted?

What is the policy for rewards and penalties?

How is knowledge transferred between construction projects regarding:

a. Construction logistics? 
b. Governance?

What are the objectives of governance? What is important to achieve? How was the solution developed?

What has been positive/negative with the chosen solution?

How is the chosen solution working in comparison to other solutions that you know of?

Would alternative logistics solutions be possible and why?

How do clients affect the logistics solution selected?

How do the logistics solution affect costs and construction efficiency?

\section{Collaboration/communication}

Can you see any difference when you have a construction organization where you have long term collaboration versus a sort term collaboration regarding how they apply logistics solutions?

What do you do to improve cooperation between parties?

What type of information should they exchange to have a good collaboration? When and how they should exchange? 


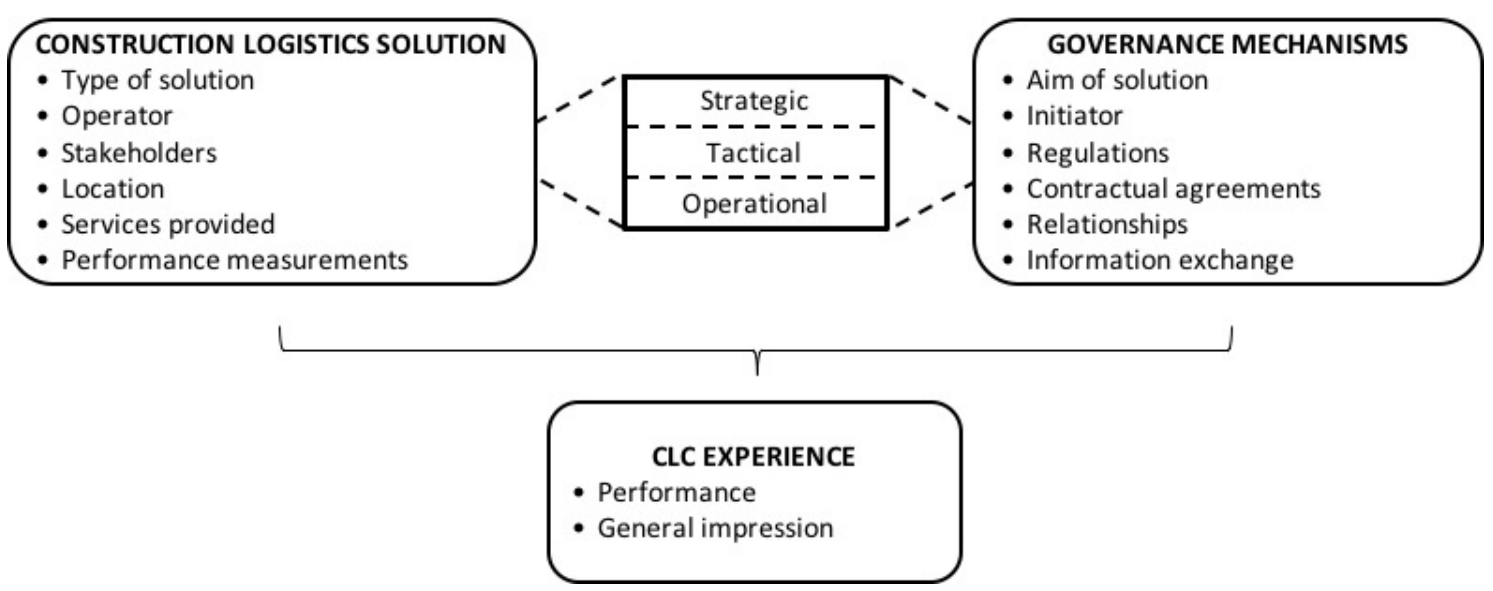

Figure 1. Analytical framework

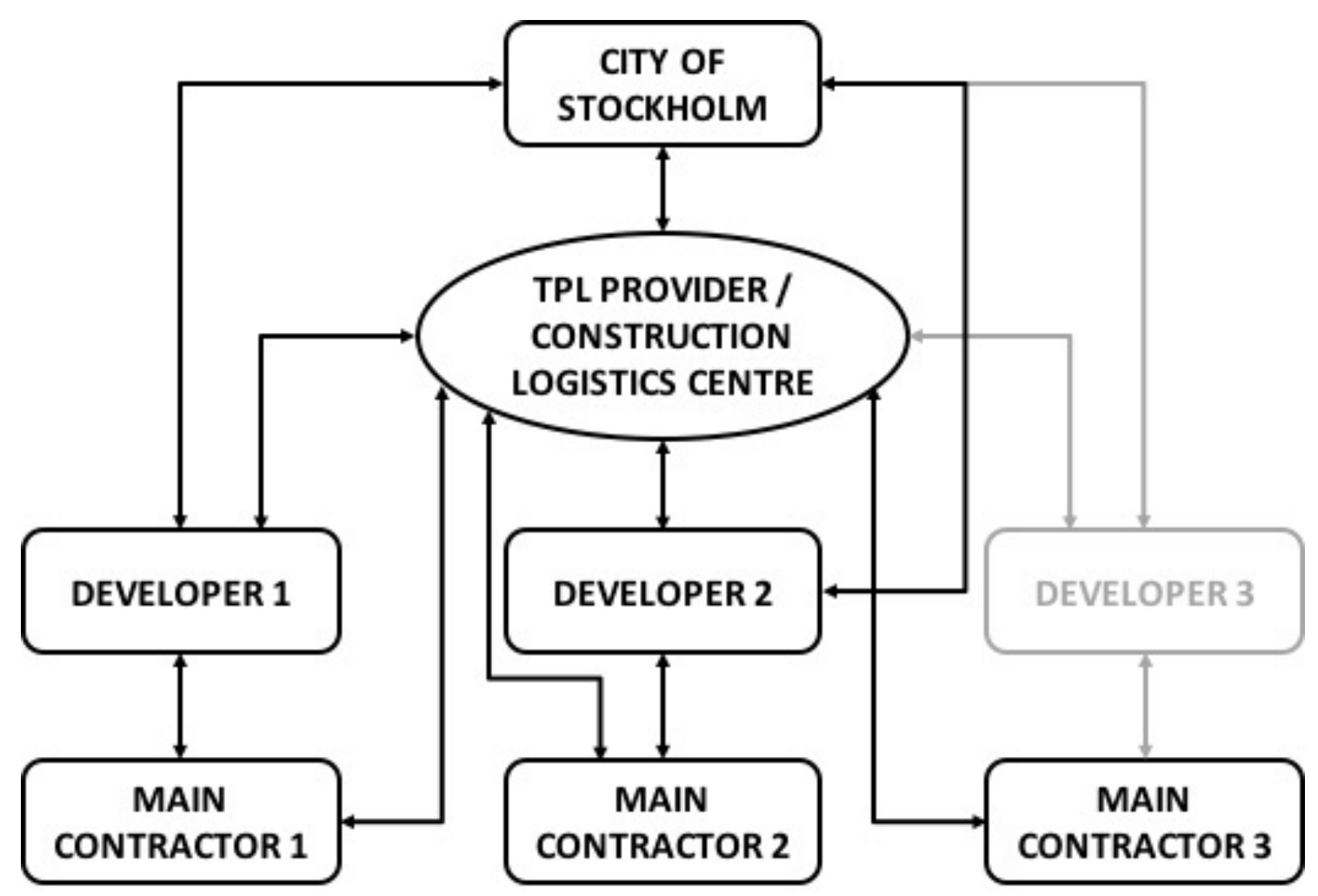

Figure 2. Relationships between the stakeholders 


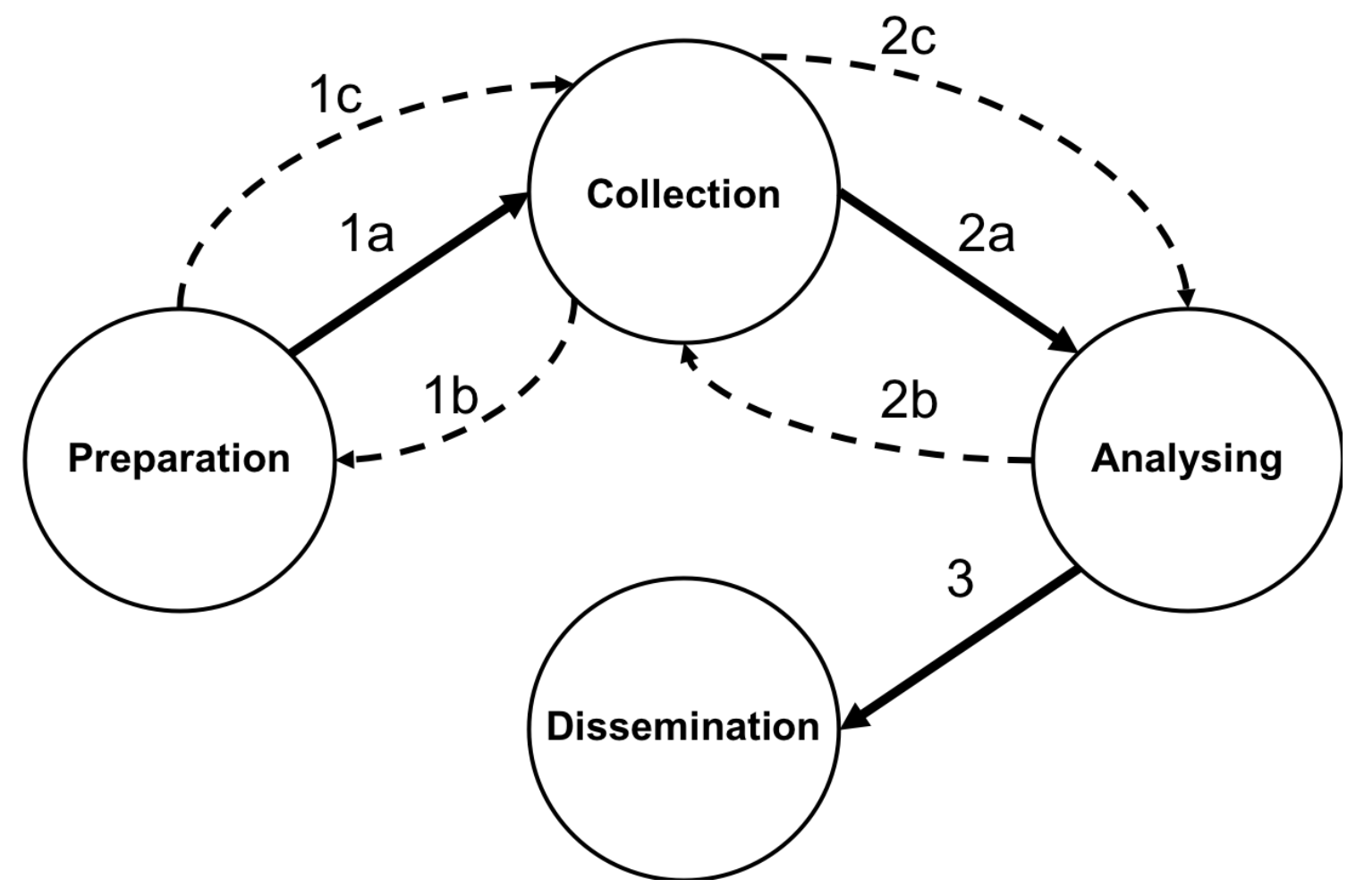

Figure 3. Research approach

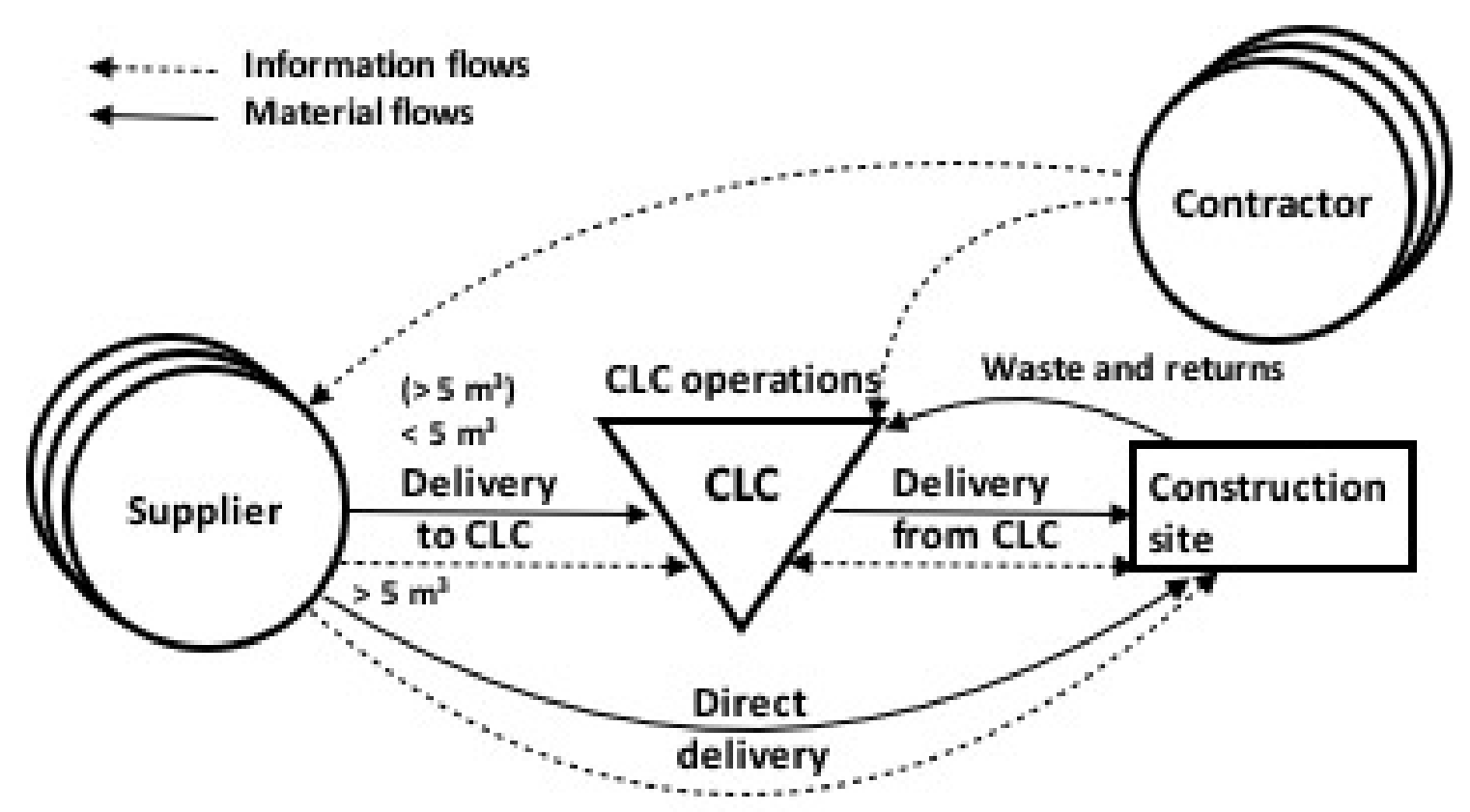

Figure 4. Functionality of the CLC at the SRS 
Table 1. The design parameters of the SRS CLC

\begin{tabular}{|c|c|}
\hline \multicolumn{2}{|r|}{ SRS CLC } \\
\hline Type of solution & $\begin{array}{l}\text { Terminal-based construction logistics centre } \\
\text { - } 2,200 \mathrm{~m}^{2} \text { climate-controlled terminal tent } \\
\text { - } 230 \mathrm{~m}^{2} \text { cold terminal tent } \\
\text { - } 1,000 \mathrm{~m}^{2} \text { waste management area } \\
\text { - } 70 \mathrm{~m}^{2} \text { office space } \\
\text { - } 3,000 \mathrm{~m}^{2} \text { of outside space }\end{array}$ \\
\hline Location & The CLC is located next to the SRS development area \\
\hline Operator & $\begin{array}{l}\text { Shared responsibility between two third-party logistics providers } \\
\text { 1. One manages the CLC and its tactical and operational } \\
\text { development } \\
\text { 2. One carries out everyday operations concerning transports, } \\
\text { warehousing and gatekeeping }\end{array}$ \\
\hline Stakeholders & $\begin{array}{l}\text { 1. Municipality of Stockholm ordered the solution and set the } \\
\text { tactical regulations of the CLC } \\
\text { 2. The two TPL providers are responsible for its operations } \\
\text { 3. Developers are contractually bound to the solution in land } \\
\text { allocation agreements and must inform and ensure that } \\
\text { contractors and sub-contractors utilise the solution; } \\
\text { developers also pay an accession fee to cover fixed costs of } \\
\text { the CLC, and some variable costs are paid per service } \\
\text { 4. Main contractors are connected to the CLC through their } \\
\text { contracts with developers; services utilised are paid per } \\
\text { service in accordance with a price plan }\end{array}$ \\
\hline
\end{tabular}




\begin{tabular}{|c|c|}
\hline provided & $\begin{array}{l}\text { 1. Short-term storage } \\
\text { 2. Transport consolidation } \\
\text { 3. Road maintenance } \\
\text { 4. Mass handling } \\
\text { 5. Return transport } \\
\text { 6. Education } \\
\text { 7. Joint geographical information system-based site layout plans } \\
\text { 8. Information to sheds } \\
\text { 10. Security } \\
\text { 11. Material ordering system } \\
\text { 12. Waste management } \\
\text { 13. Cleaning and sanitation }\end{array}$ \\
\hline $\begin{array}{l}\text { Additional } \\
\text { services provided }\end{array}$ & $\begin{array}{l}\text { 1. On-site materials handling } \\
\text { 2. Logistics coordination } \\
\text { 3. External long-term storage } \\
\text { 4. Kitting } \\
\text { 5. On-site waste management } \\
\text { 6. Loading, unloading and lifting vehicles } \\
\text { 7. Special vehicles }\end{array}$ \\
\hline $\begin{array}{l}\text { Performance } \\
\text { measurements }\end{array}$ & $\begin{array}{l}\text { 1. Cost follow-up } \\
\text { 2. Delivery performance } \\
\text { 3. Number of gate passages } \\
\text { 4. Number of deliveries } \\
\text { 5. Handling time }\end{array}$ \\
\hline
\end{tabular}


6. Storage utilisation

7. Service utilisation

Table 2. Summary of the stakeholders' positive and negative experiences of the SRS CLC.

\begin{tabular}{|c|c|c|}
\hline \multicolumn{3}{|c|}{ Stakeholder Experiences } \\
\hline & Performance & General impression \\
\hline City of Stockholm & $\begin{array}{l}+ \text { Consolidation effect } \\
+ \text { Control of materials in } \\
\text { SRS area }\end{array}$ & $\begin{array}{l}\text { + Worked well as a } \\
\text { coordination measure } \\
\text { - Long information chains } \\
\text { and poor knowledge transfer } \\
\text { from developers/clients } \\
\text { - Reluctance to use CLC } \\
\text { from developers/clients and } \\
\text { contractors }\end{array}$ \\
\hline TPL operator & $\begin{array}{l}+ \text { Consolidation effect } \\
+ \text { Control of materials in } \\
\text { SRS area }\end{array}$ & $\begin{array}{l}\text { - Apprehensive contractors } \\
\text { - Difficult to show value of } \\
\text { additional services } \\
\text { - Room for development of } \\
\text { services and governance } \\
\text { mechanisms } \\
\text { - Contractors not complying } \\
\text { with transport time windows }\end{array}$ \\
\hline
\end{tabular}




\begin{tabular}{|c|c|c|}
\hline Developers & $\begin{array}{l}\text { + Coordination effect } \\
+ \text { Working in similar } \\
\text { conditions would be } \\
\text { difficult without a } \\
\text { construction logistics } \\
\text { solution } \\
+ \text { Good contact with city } \\
\text { and TPL with learning from } \\
\text { experience }\end{array}$ & $\begin{array}{l}\text { - Poor construction } \\
\text { knowledge from city and } \\
\text { TPL provider } \\
\text { - Unfeasible regulations } \\
\text { connected to the CLC } \\
\text { - Development of CLC and } \\
\text { regulations did not consider } \\
\text { end-users (i.e. developers and } \\
\text { contractors) } \\
\text { - Issues with information and } \\
\text { knowledge exchange }\end{array}$ \\
\hline Main contractors & $\begin{array}{l}\text { + Coordination of different } \\
\text { main contractors } \\
+ \text { Consolidation effect } \\
+ \text { Increased and better } \\
\text { planning } \\
+ \text { Smoother delivery } \\
\text { process with call-offs from } \\
\text { CLC } \\
\text { - CLC sold in as cost } \\
\text { saving, yet logistics costs } \\
\text { are increased } \\
\text { - Longer lead times } \\
\text { - Early delivery issues }\end{array}$ & $\begin{array}{l}\text { + Working in similar } \\
\text { conditions would be difficult } \\
\text { without a construction } \\
\text { logistics solution } \\
\text { - Poor knowledge transfer } \\
\text { from developers/clients } \\
\text { - Poor construction } \\
\text { knowledge from city } \\
\text { - CLC not developed for all } \\
\text { stages of construction }\end{array}$ \\
\hline
\end{tabular}




\begin{tabular}{|l|l|l|}
\hline & $\begin{array}{l}- \text { CLC not suited for large } \\
\text { materials }\end{array}$ & \\
\hline
\end{tabular}

Table 3. Guidelines and performance impact on strategic, tactical and operational level

\begin{tabular}{|c|c|c|c|c|}
\hline & $\begin{array}{l}\text { Case } \\
\text { observation }\end{array}$ & Guideline & Outcome & $\begin{array}{l}\text { Performance } \\
\text { measure }\end{array}$ \\
\hline Strategic & $\begin{array}{l}\text { Location of } \\
\text { terminal } \\
\text { affects goal } \\
\text { fulfilment }\end{array}$ & $\begin{array}{l}\text { The location } \\
\text { of a CLC must } \\
\text { take the whole } \\
\text { delivery chain } \\
\text { into } \\
\text { consideration } \\
\text { and be based } \\
\text { on a thorough } \\
\text { logistics } \\
\text { analysis to } \\
\text { achieve its } \\
\text { goal }\end{array}$ & $\begin{array}{l}\text { - If the CLC is } \\
\text { located further } \\
\text { away, improved } \\
\text { consolidation } \\
\text { effects can be } \\
\text { achieved } \\
\text { If the CLC is } \\
\text { located close to } \\
\text { development area, } \\
\text { TPL provider can } \\
\text { help with } \\
\text { coordination of } \\
\text { stakeholders } \\
\text { within } \\
\text { development area }\end{array}$ & $\begin{array}{l}\text { Environmenta } \\
1 \\
\text { (consolidation } \\
\text { effect, } \\
\text { emissions and } \\
\text { no. of } \\
\text { transports) }\end{array}$ \\
\hline Strategic & $\begin{array}{l}\text { The CLC } \\
\text { was }\end{array}$ & $\begin{array}{l}\text { Clearly state } \\
\text { and specify }\end{array}$ & $\begin{array}{l}\text { Increases } \\
\text { acceptance of the }\end{array}$ & Cost \\
\hline
\end{tabular}




\begin{tabular}{|c|c|c|c|c|}
\hline & $\begin{array}{l}\text { promoted as } \\
\text { cost saving, } \\
\text { rather than } \\
\text { highlighting } \\
\text { the primary } \\
\text { goal of } \\
\text { reducing } \\
\text { impact on } \\
\text { third } \\
\text { parties. } \\
\text { Contrary to } \\
\text { saving on } \\
\text { costs, the } \\
\text { CLC led to } \\
\text { increased } \\
\text { logistics for }\end{array}$ & $\begin{array}{l}\text { the main goal } \\
\text { of the CLC }\end{array}$ & $\begin{array}{l}\text { solution amongst } \\
\text { developers, main, } \\
\text { and sub- } \\
\text { contractors } \\
\text { Developers and } \\
\text { contractors can } \\
\text { thus budget for the } \\
\text { increased costs of } \\
\text { logistics } \\
\text { If this goal is } \\
\text { conflicting with } \\
\text { goal of contractors } \\
\text { and developers, it } \\
\text { allows them to } \\
\text { plan for the }\end{array}$ & \\
\hline Tactical & $\begin{array}{l}\text { Terminal } \\
\text { solutions } \\
\text { add to } \\
\text { delivery } \\
\text { lead times } \\
\text { and } \\
\text { handling }\end{array}$ & $\begin{array}{l}\text { Clarify and } \\
\text { specify the } \\
\text { operational } \\
\text { possibilities } \\
\text { and limitations } \\
\text { of CLCs in } \\
\text { order to } \\
\text { clarify the }\end{array}$ & $\begin{array}{l}\text { Increases } \\
\text { acceptance of the } \\
\text { solution amongst } \\
\text { main and sub- } \\
\text { contractors } \\
\text { Allows contractors } \\
\text { to plan their } \\
\text { material deliveries }\end{array}$ & Delivery \\
\hline
\end{tabular}




\begin{tabular}{|c|c|c|c|c|}
\hline & & $\begin{array}{l}\text { potential of } \\
\text { CLCs }\end{array}$ & $\begin{array}{l}\text { in accordance with } \\
\text { prolonged delivery } \\
\text { lead times } \\
\text { - Allows contractors } \\
\text { to plan for utilizing } \\
\text { the warehousing } \\
\text { capabilities of the } \\
\text { CLC }\end{array}$ & \\
\hline Tactical & $\begin{array}{l}\text { Long } \\
\text { information } \\
\text { chains lead } \\
\text { to unclear } \\
\text { information } \\
\text { exchange }\end{array}$ & $\begin{array}{l}\text { It must be } \\
\text { clearly } \\
\text { stipulated for } \\
\text { all } \\
\text { stakeholders } \\
\text { what is } \\
\text { expected from } \\
\text { them in } \\
\text { connection to } \\
\text { the CLC }\end{array}$ & $\begin{array}{l}\text { Clear information } \\
\text { and } \\
\text { communication } \\
\text { lead to greater } \\
\text { acceptance of } \\
\text { solution }\end{array}$ & $\begin{array}{l}\text { Flexibility and } \\
\text { quality }\end{array}$ \\
\hline Tactical & $\begin{array}{l}\text { Level of } \\
\text { regulatory } \\
\text { detail } \\
\text { affects the } \\
\text { compliance } \\
\text { of the } \\
\text { solution }\end{array}$ & $\begin{array}{l}\text { Regulations } \\
\text { should be set } \\
\text { early on in the } \\
\text { strategic } \\
\text { development } \\
\text { of the CLC. }\end{array}$ & $\begin{array}{l}\text { - If detailed } \\
\text { regulations are set, } \\
\text { they will need to } \\
\text { be adaptable in the } \\
\text { operational phase } \\
\text { to ensure }\end{array}$ & Flexibility \\
\hline
\end{tabular}




\begin{tabular}{|c|c|c|c|c|}
\hline & & & $\begin{array}{l}\text { acceptance of the } \\
\text { CLC } \\
\text { - If more general } \\
\text { rules are set on the } \\
\text { strategic level, } \\
\text { these can be } \\
\text { further detailed on } \\
\text { a tactical level } \\
\text { once the affected } \\
\text { stakeholders are } \\
\text { identified } \\
\text { This allows for } \\
\text { stakeholder } \\
\text { involvement early } \\
\text { on }\end{array}$ & \\
\hline Tactical & $\begin{array}{l}\text { Finding the } \\
\text { right } \\
\text { operator is } \\
\text { critical }\end{array}$ & $\begin{array}{l}\text { Try to find an } \\
\text { operator that } \\
\text { is } \\
\text { knowledgeabl } \\
\text { e in both } \\
\text { construction } \\
\text { and logistics; } \\
\text { if this is not } \\
\text { possible, the } \\
\text { aim of the }\end{array}$ & $\begin{array}{l}\text { Both logistics and } \\
\text { construction } \\
\text { knowledge will } \\
\text { allow the operator } \\
\text { to offer best } \\
\text { possible services } \\
\text { Logistics } \\
\text { competence } \\
\text { positively affect } \\
\text { construction }\end{array}$ & $\begin{array}{l}\text { Flexibility, } \\
\text { quality and } \\
\text { costs }\end{array}$ \\
\hline
\end{tabular}




\begin{tabular}{|c|c|c|c|c|}
\hline & & $\begin{array}{l}\text { solution } \\
\text { should be used } \\
\text { to indicate } \\
\text { which } \\
\text { competence is } \\
\text { most } \\
\text { important. }\end{array}$ & $\begin{array}{l}\text { logistics solutions } \\
\text { with a city } \\
\text { logistics aim } \\
\text { - Construction } \\
\text { competence } \\
\text { positively affect } \\
\text { construction } \\
\text { logistics solutions } \\
\text { where construction } \\
\text { sites and project } \\
\text { productivity are } \\
\text { the most important } \\
\text { aspects to consider }\end{array}$ & \\
\hline $\begin{array}{l}\text { Operationa } \\
1\end{array}$ & $\begin{array}{l}\text { Terminal } \\
\text { solutions } \\
\text { may not be } \\
\text { able to } \\
\text { manage all } \\
\text { types of } \\
\text { materials }\end{array}$ & $\begin{array}{l}\text { Add flexibility } \\
\text { into the } \\
\text { regulations } \\
\text { regarding } \\
\text { what materials } \\
\text { have to go } \\
\text { through the } \\
\text { CLC. } \\
\text { The solution } \\
\text { need to be } \\
\text { adaptable to } \\
\text { handle the }\end{array}$ & $\begin{array}{l}\text { - Allows contractor } \\
\text { to utilize the CLC } \\
\text { when applicable } \\
\text { - The TPL provider } \\
\text { can focus on } \\
\text { providing suitable } \\
\text { services for } \\
\text { materials they can } \\
\text { handle at the } \\
\text { terminal }\end{array}$ & $\begin{array}{l}\text { Flexibility and } \\
\text { delivery }\end{array}$ \\
\hline
\end{tabular}




\begin{tabular}{|c|c|c|c|c|}
\hline & & $\begin{array}{l}\text { variation in } \\
\text { materials } \\
\text { during the } \\
\text { construction } \\
\text { project in an } \\
\text { efficient way. }\end{array}$ & & \\
\hline $\begin{array}{l}\text { Operationa } \\
1\end{array}$ & $\begin{array}{l}\text { Clear } \\
\text { authority of } \\
\text { the CLC } \\
\text { operator } \\
\text { affects } \\
\text { relationship } \\
\text { s and } \\
\text { services } \\
\text { provided }\end{array}$ & $\begin{array}{l}\text { The operating } \\
\text { TPL provider } \\
\text { should be } \\
\text { granted some } \\
\text { authority and } \\
\text { autonomy to } \\
\text { ensure that } \\
\text { operations run } \\
\text { smoothly }\end{array}$ & $\begin{array}{l}\text { Allows for one } \\
\text { point of contact } \\
\text { when it comes to } \\
\text { regulatory } \\
\text { questions } \\
\text { Leads to flexibility } \\
\text { in services } \\
\text { provided to } \\
\text { contractors }\end{array}$ & $\begin{array}{l}\text { Flexibility and } \\
\text { delivery }\end{array}$ \\
\hline $\begin{array}{l}\text { Operationa } \\
1\end{array}$ & $\begin{array}{l}\text { Projects } \\
\text { with logistic } \\
\text { managers at } \\
\text { site are } \\
\text { more prone } \\
\text { to utilise the } \\
\text { CLC }\end{array}$ & $\begin{array}{l}\text { Specify that } \\
\text { logistics } \\
\text { manager is } \\
\text { required in } \\
\text { land allocation } \\
\text { agreement }\end{array}$ & $\begin{array}{l}\text { - Coordination } \\
\text { effect amongst } \\
\text { stakeholders, } \\
\text { especially between } \\
\text { contractors, and in } \\
\text { the contractor TPL } \\
\text { provider } \\
\text { relationship } \\
\text { Increased chances } \\
\text { for good }\end{array}$ & $\begin{array}{l}\text { Flexibility, } \\
\text { quality, } \\
\text { environmental } \\
\text { and costs }\end{array}$ \\
\hline
\end{tabular}




\begin{tabular}{|l|l|l|l|}
\hline & & relationship/contac \\
& & & $\mathrm{t}$ with city and TPL \\
provider & \\
\hline
\end{tabular}

